\title{
Diversity patterns and zoogeography of the Northeast Atlantic and Mediterranean shallow-water sponge fauna
}

\author{
Joana R. Xavier • Rob W. M. Van Soest
}

Received: 24 February 2011/Accepted: 6 September 2011/Published online: 6 October 2011

(C) The Author(s) 2011. This article is published with open access at Springerlink.com

\begin{abstract}
Recognizing and understanding presentday biodiversity and biogeographical patterns and how these relate to contemporary and past climate is pivotal to predict the effect of future climate on marine biodiversity and promote adequate conservation policies. Sponges constitute an important and dominant component of the marine benthos and are therefore an excellent model group for such investigations. In this study, we assessed the diversity patterns and the
\end{abstract}

Guest editors: M. Maldonado, X. Turon, M. A. Becerro \& M. J. Uriz / Ancient animals, new challenges: developments in sponge research

\section{J. R. Xavier}

Evolutionary Biology, Institute for Biodiversity and Ecosystem Dynamics (IBED), University of Amsterdam, Kruislaan 318, 1098 SM Amsterdam, The Netherlands

J. R. Xavier ( $\square)$

CIBIO-Research Centre in Biodiversity and Genetic Resources, CIBIO-Azores, University of the Azores, Biology Department, Rua Mãe de Deus 13A, 9501-801 Ponta Delgada, Portugal

e-mail: jxavier@uac.pt

J. R. Xavier

CEAB - Centre for Advanced Studies of Blanes (CSIC), Camí d'accés a la Cala S. Francesc, 14, 17300 Blanes, Girona, Spain

\section{R. W. M. Van Soest}

Netherlands Centre for Biodiversity, Zoological Museum of Amsterdam, P.O. Box 94766, 1090 GT Amsterdam, The Netherlands zoogeographical affinities of the Northeast Atlantic and Mediterranean shallow-water demosponge assemblages. Data on the distribution of 745 species throughout 28 areas was compiled from the literature and used to build a presence/absence matrix. Diversity patterns were assessed from estimates of species richness $(S)$ and taxonomic distinctness (AvTD). The Mediterranean Sea proved to be more diverse both in terms of species richness and taxonomic distinctness $(S=539$, AvTD $=94.74)$ than the Northeast Atlantic $(S=480$, AvTD $=92.42)$ and the two regions together were found to constitute a diversity hotspot harbouring approximately $11 \%$ of the global demosponge diversity. We found an Atlantic N-S and a Mediterranean NW-SE gradient of increasing taxonomic distinctness that is strongly correlated to both contemporary $\left(R^{2}=0.5667 ; P<0.01\right)$ and historical values $\left(R^{2}=0.7287 ; P<0.01\right)$ of sea surface temperature (SST) at the Last Glacial Maximum (LGM). The zoogeographical affinities examined through classification (cluster analysis) and ordination (nonmetric multidimensional scaling, nMDS) based on the Bray-Curtis similarity index, revealed the presence of three groups approximately corresponding to the Northern European Seas, Lusitanian and Mediterranean provinces outlined in the 'Marine Ecoregions of the World' (MEOW) classification system. Geographical distance and oceanographic circulation were shown to constitute important factors in shaping the zoogeographical affinities among areas. The vast majority of the species occurring in the Northeast 
Atlantic and the Mediterranean (67 and 57\%, respectively) was shown to have extremely restricted geographical ranges, as single-area or narrow-range (2-3 areas) endemics, which raises some concerns regarding their conservation.

Keywords Porifera - Demospongiae · Biogeography $\cdot$ Marine biodiversity $\cdot$ Paleoclimate . Taxonomic distinctness

\section{Introduction}

The study of the patterns and the underlying processes of origin and maintenance of diversity from populations to ecosystems and how these relate to contemporary and historical factors are the focus of disciplines such as ecology, biogeography and phylogeography. The shallow waters of the AtlantoMediterranean region encompass an important area covering a wide climatic range of subtropical, temperate and subarctic conditions. Since its formation, the Northeast Atlantic and Mediterranean have experienced an intricate geological and climatological history, with major events such as the Messinian Salinity Crisis (5.96-5.33 Myr BP) in the late Miocene and the formation of permanent ice sheets ( $\approx 3 \mathrm{Myr}$ BP) at high northern latitudes at the onset of the Quaternary oscillations between cold glacial and warm interglacial periods (the Pleistocene glaciations). The last glacial cycle, from $130 \mathrm{kyr}$ BP to the present, culminated in the Last Glacial Maximum (LGM, 30-19 kyr BP) during which the North Atlantic and Mediterranean shores endured glacial conditions with the advance of the major ice sheets and concomitant drop in sea surface temperature (SST), eustatic sea-level fluctuations, and changes in surface circulation patterns (Lambeck et al., 2002; Pflaumamm et al., 2003; Hayes et al., 2005). This event produced great changes in species distributions: some went extinct over large parts of their range or dispersed to new areas, while others survived in refugia, leaving a traceable genetic imprint in its populations. While the effects at the intraspecific level are relatively well documented (Hewitt, 1996, 1999, 2000, 2004), the effects on the diversity patterns of regional assemblages are far less known (e.g. Jansson, 2003; Araújo et al., 2008). Within the marine realm, the most compelling evidence of such effects emerge from phylogeographic studies that have identified structured populations and signatures of refugia, as well as range-expansion for several Atlanto-Mediterranean species (see reviews in Patarnello et al., 2007; Maggs et al., 2008).

Sponges are one of the dominant invertebrate groups of hard-bottom benthic communities, both in terms of biomass and species richness, and they play important roles in ecosystem functioning throughout temperate, tropical and polar habitats (Sarà \& Vacelet, 1973; Bell, 2008). Yet, studies on the diversity and distribution patterns of sponge faunas at alpha, beta or gamma scales remain few (e.g. Hooper \& Kennedy, 2002; Samaai, 2006; Van Soest et al., 2007a), and an even smaller number of studies have attempted to relate the observed patterns to ecological variables (e.g. de Voogd et al., 2006; de Voogd \& Cleary, 2007; Van Soest et al., 2007a).

Sponges are sessile in their adult stage and exhibit low dispersal capabilities during their larval stage, due to the production of lecithotrophic larvae with a short life span and philopatric behaviour (Mariani et al., 2005, 2006; Maldonado, 2006; Uriz et al., 2008). As in many other marine organisms, the reproductive timing in sponges is highly correlated with water temperature (see Riesgo \& Maldonado, 2008 and references therein). Taking these characteristics into account, we hypothesise that when examined over a large spatial scale, the demosponge fauna should exhibit clear zoogeographical and diversity patterns with a signature of the geological and paleoclimatic events of the Mio-Pleistocene.

Some previous studies examined the zoogeographical affinities of the sponge fauna in the Northeast Atlantic and Mediterranean, but these mostly focused on particular areas within this region such as Cape Verde and Mauritania (Van Soest, 1993a, b), Strait of Gibraltar (Carballo et al., 1997), Alboran Sea (Maldonado \& Uriz, 1995) or the Aegean Sea (Voultsiadou, 2005). Pansini \& Longo (2003), followed by Voultsiadou (2009), were the first to provide a comprehensive account of the diversity and biogeography of the Mediterranean sponges. Both studies recognized the contribution of the Atlantic Ocean to the diversity patterns seen in the Mediterranean, but the lack of an analysis combining data from both areas has obscured our understanding of the relationship between them. The present work aims to uncover the diversity 
patterns and zoogeographical affinities of the shallowwater demosponge fauna of the entire Northeast Atlantic and Mediterranean region, and determine to which extent these patterns are related to the climatic and geological events of the late Pleistocene.

\section{Methods}

Study area

Our study encompasses the area located approximately between latitudes $15-70^{\circ} \mathrm{N}$ and longitudes $32^{\circ} \mathrm{W}-35^{\circ} \mathrm{E}$ (Fig. 1). According to the Marine Ecoregions of the World (MEOW) classification system (Spalding et al., 2007), this area comprises four provinces (Northern European Seas, Lusitanian,
Mediterranean Sea, and West African Transition) and 17 out of the 19 marine ecoregions (excl. Iceland and the Baltic Sea) nested within these provinces.

\section{Species distribution data}

Among the three extant classes of the Porifera, the Demospongiae is the most speciose group harbouring approximately $85 \%$ of all sponge species (Van Soest et al., 2009). The two remaining classes, Calcarea and Hexactinellida account for a much smaller proportion of species. As the former are much in need of taxonomic revision and the latter are mostly restricted to the deep-sea environment (Hooper \& Van Soest, 2002), these lesser groups have been excluded from the analyses. Given that shallow and deep-water sponge assemblages differ in species composition, in

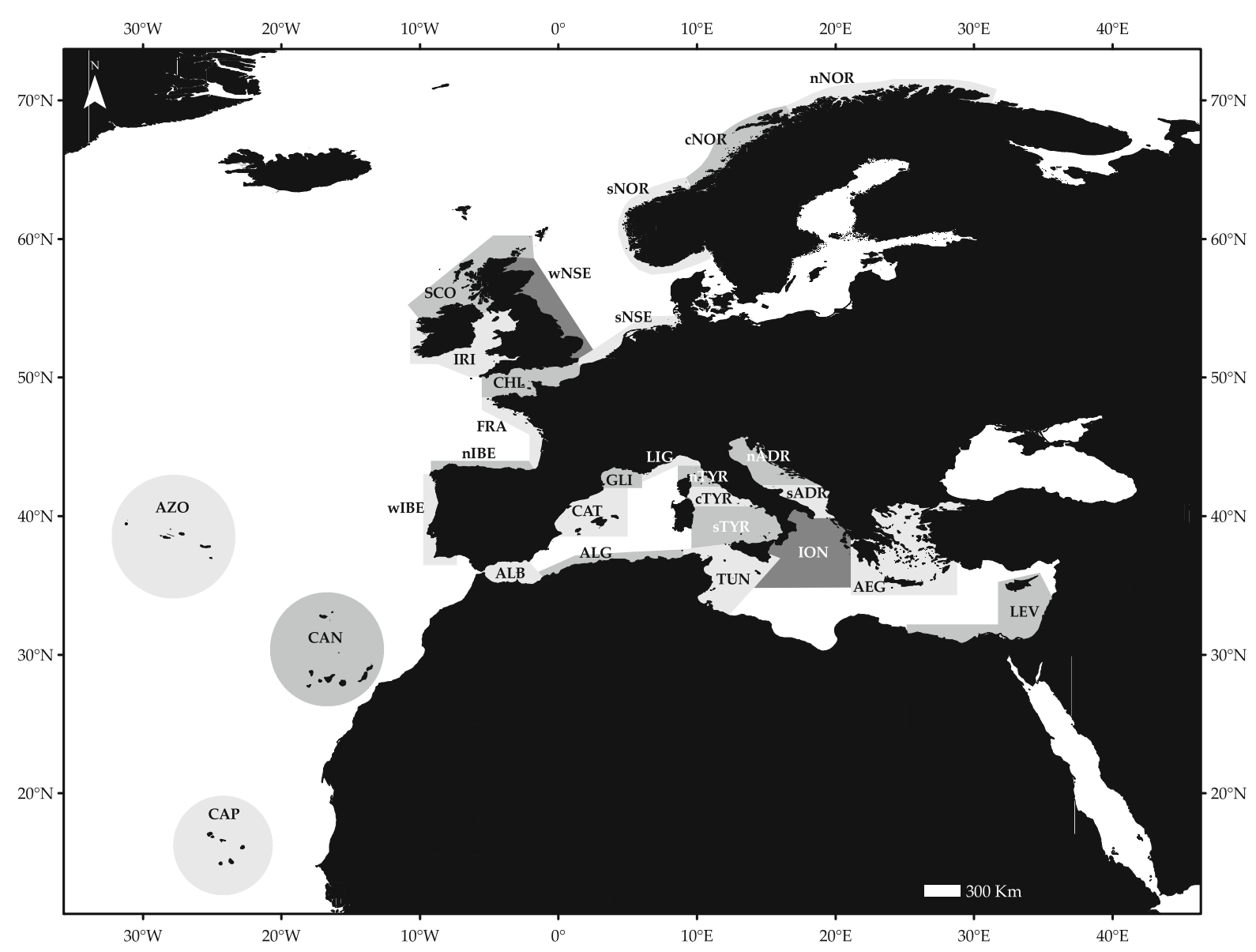

Fig. 1 The Northeast Atlantic and Mediterranean Sea, highlighting the areas considered in this study (Mediterranean areas were redrawn from Pansini \& Longo, 2003). For area codes see "Methods" section 
this comparison we have only taken into account species inhabiting the sublittoral and circalittoral zones to an approximate depth of $120 \mathrm{~m}$.

Species distributions (presence/absence) were compiled from the literature, which covers an approximately 115 year-period of publications concerning the Northeast Atlantic and Mediterranean sponge fauna (e.g. Topsent, 1892; Vacelet et al., 2007). We have collected data covering a total of 14 Northeast Atlantic and 14 Mediterranean areas (Fig. 1). These areas were delimited on the basis of either the geographical orientation of a coastal segment (e.g. West and North coasts of the Iberian Peninsula) or natural isolation (e.g. Canary or Azores islands), and for which a relatively well-studied sponge fauna was available.

The Northeast Atlantic was divided into (main data sources in parentheses): AZO_Azores archipelago (Topsent, 1892, 1904; Boury-Esnault \& Lopes, 1985; De Weerdt \& Van Soest, 1986; Moss, 1992; Xavier, 2003; J. Xavier, unpublished data); CAN-Canary islands (Cruz, 1980, 1984, 2002; Cruz \& Bacallado, 1982, 1983, 1984, 1985a, b) also including Madeira island (Johnson, 1899; Topsent, 1928; Lopes, 1995; Pestana, 2002; J. Xavier, unpublished data); CAPCape Verde also including Mauritania (Van Soest, 1993a, b); wIBE — West coast of the Iberian Peninsula (Portugal and Spain) (Hanitsch, 1895; Lévi \& Vacelet, 1958; Lopes \& Boury-Esnault, 1981; Lopes, 1989; Naveiro, 2002; Pires, 2007; J. Xavier, unpublished data) also including the Gorringe Bank (Xavier \& Van Soest, 2007); nIBE-North coast of Spain (Ferrer-Hernández, 1914, 1918, 1922; Solórzano, 1991; Cristobo, 1997; Preciado, 2002); FRA-West coast of France (Descatoire, 1966, 1969); CHLEnglish Channel (Burton, 1930, 1957; Borley, 1931; Lévi, 1950; Borojevic et al., 1968; Cabioch, 1968, 1973; Cabioch \& Glaçon, 1975; Ackers et al., 1992); IRI-Irish and Celtic Seas (Burton, 1963; Van Soest \& Weinberg, 1980; Van Soest et al., 1983; Hiscock et al., 1984; Ackers et al., 1992; Bell \& Barnes, 2000); SCO — North coast of Scotland and Ireland (Ackers et al., 1992; Picton \& Goodwin, 2007); sNSE, wNSESouth and West coasts of the North Sea (Topsent, 1899; Ackers et al., 1992; Van Soest et al., 2007b; M. de Kluijver, unpublished data); sNOR, wNOR and nNOR - South, West and North coasts of Norway (Tendal et al., 2001; Hans Tore Rapp, pers. comm.).

For the Mediterranean areas, we followed the matrix in Pansini \& Longo (2003), removed the deep-sea species and complemented the data of the shallow-water species for some areas with later studies (e.g. Kefalas et al., 2003; Voultsiadou, 2005; Kefalas \& Castritsi-Catharios, 2007 for the Aegean Sea; Vacelet et al., 2007 for the Lebanon coast; Mustapha et al., 2003 for Tunisia). The areas considered in the Mediterranean were: ALB-Alboran Sea; CATCatalunya and Balearic islands; GLI-Golfe du Lion; ALG-Algerian Basin; LIG-Ligurian Sea; n, c, sTYR - North, Central and South Tyrrhenian Sea; TUN-Tunisian coast, Malta and southwest Sicily; n, sADR - North and South Adriatic; ION-Ionian Sea; AEG-Aegean Sea; and LEV-Levantine Basin including the coast of Egypt. Some of the studies we consulted have a larger geographical coverage (e.g. Topsent, 1892, 1928; Van Soest et al., 2000).

Species lists were extracted from each reference, compiled for each area and then aggregated, eliminating redundant records. These lists were crosschecked with the World Porifera Database (WPD, Van Soest et al., 2009 available at: http://www.marinespecies. org/porifera/) and only valid names were considered. These lists were then compiled into a distribution matrix which has approximately 21,000 records (745 spp. $\times 28$ areas).

Diversity: species richness $(S)$ and taxonomic distinctness (AvTD)

Species richness $(S)$ is a diversity measure commonly used when no quantitative information is available. However, making comparisons and interpretations based on this measure is difficult as it is highly dependent on sampling effort (Clarke \& Warwick, 2001a). Given that we have assembled our data from an extremely heterogeneous array of sources, in terms of sampling techniques and intensity, this measure will only be used as indicative.

Average taxonomic distinctness (AvTD or $\Delta^{+}$), developed by Warwick \& Clarke (1995), is a diversitymeasure that takes into account the relationships between species following a Linnean classification. For presence/absence data, the AvTD of an assemblage at a particular area (a species list) is defined as the average taxonomic distance (path length) between all its species pairs, measured along the classification tree. This approach is therefore an indicative measure of the taxonomic 'breadth' of an assemblage and the relatedness of its constituent species (Clarke \& 
Warwick, 1998). The advantages of the AvTD over simple species-richness estimates are that AvTD captures 'phylogenetic' diversity and is robust to variation in sampling effort (Clarke \& Warwick, 1998; Warwick \& Clarke, 1998). These statistical properties make this method particularly suitable for analyses of historic data, i.e. data which does not follow a standardised sampling design or effort (Clarke \& Warwick, 1998). Another advantage of this method is that, contrary to the species-richness measure, it allows a test for departure from expectation, i.e. it compares the taxonomic distinctness of a location with the one which would be expected if that assemblage had been randomly drawn from the total species pool present in the wider area (master list). As an example, considering the Azores list of size $S=95$, the method will randomly extract sublists of the same size from the complete species list of the Northeast Atlantic and compute the AvTD values for each of these lists. From the AvTD-simulated values, it will construct a histogram of the expected range of AvTD values for sublists of that size. If the observed AvTD falls outside the $95 \%$ confidence interval of the simulated $\Delta^{+}$, it is considered to have departed significantly from expectation, thus reflecting enhanced or reduced diversity of the Azorean assemblage. Because the $95 \%$ expectation interval was calculated from the master list from which the species have been drawn at random, and because we found a large proportion of species that are endemic to either the Northeast Atlantic or the Mediterranean (see 'Results' section), we further calculated this interval using only Mediterranean or Atlantic locations. Note that the AvTD value for each area remains the same and that only the $95 \%$ funnel boundaries and mean AvTD are re-adjusted, due to the change of the master list. Thus, this analysis provides a more accurate estimate of the distinctness of these areas' assemblages, relative to expectation, within their geographical contexts.

Another index associated with the AvTD is the variation in taxonomic distinctness (varTD or $\Lambda^{+}$), which measures the variance of the pairwise path lengths and reflects the unevenness of the taxonomic tree, i.e. the assemblage (Clarke \& Warwick, 2001b). A presence/absence data matrix and an aggregation file containing the taxonomic classification of the species in the data matrix are the basis for these analyses. Because the assemblages studied here are restricted to the Class Demospongiae, we have considered four phylogenetic levels: species, genus, family and order (e.g. Oscarella lobularis; Oscarella; Plakinidae; Homosclerophorida) and constant step lengths between levels (Clarke \& Warwick, 1999). The analyses were performed through the TAXDTEST routine in Primer v. 6.1.11 (Clarke \& Gorley, 2006).

Correlation between taxonomic distinctness (AvTD) and climate (SST)

Using taxonomic distinctness as a measure of assemblage diversity, we tested whether the observed pattern was more correlated with contemporary or historical values of SST, as this factor is known to be a critical one for species distribution (Sarà \& Vacelet, 1973). The SST data used was that resulting from the project 'Climate: long range investigation, mapping and prediction' (CLIMAP, 1976, 1981, 1984). In order to make use of this data, we averaged the values of mean contemporary SST and mean SST anomaly (LGM-contemporary) for each area and performed a linear regression analyses between these and the values of AvTD.

\section{Zoogeographical affinities: cluster analysis}

From the presence/absence data matrix we built a pairwise similarity matrix employing the Bray-Curtis coefficient. Hierarchical agglomerative clustering and non-metric multidimensional scaling (nMDS) were performed to assess the faunistic similarities between areas. In order to assure convergence to the global minimum of stress, which is a goodness-of-fit measure of the representation in the $2 \mathrm{D}$ space, we performed several MDS runs with 50 random starts (stress $<0.1$ corresponds to a good ordination with no prospect for misleading interpretations). These analyses were carried out for both species and genera.

Using a similarity percentage routine (SIMPER), we assessed the extent of similarity within the Northeast Atlantic and Mediterranean regions, as well as the dissimilarity between these two areas. A matrix was built with geographical marine distances between each pair of locations, and then analysed along with a Bray-Curtis similarity matrix through non-parametric correlation (Spearman's rank correlation) in order to ascertain the role of geographical distance in the zoogeographical affinities among areas. This was performed using Primer's RELATE routine. 
Species affinities and geographical range

The zoogeographical affinities of the species were assessed through classification of each species into Atlanto-Mediterranean (AM), Atlantic endemic (AE) and Mediterranean endemic (ME). Distribution ranges were classified into: single-area occurrence (sa) if a species is reported in the literature for only one of the considered areas; a narrow-ranged (nr) occurrence if a species is found in two or three out of the 14 Northeast Atlantic or Mediterranean areas; and a wide-ranged (wr) occurence if a species is found in four or more areas. As an example, a species which occurs in only one Atlantic area would be classified as a single-area Atlantic endemic (or saAE), while one occurring in six Mediterranean regions would be classified as a wideranged Mediterranean endemic (wrME). Note that the term endemic here stands for species that occur either in the NEA or MED, and that we do not take into account whether the species occurs in other regions outside our study area.

\section{Results}

Diversity: species richness and taxonomic distinctness

The sponge literature yielded data on the distribution of 745 shallow-water demosponge species occurring in the study area. This value encompasses 187 genera in 64 families and 14 orders and represents approximately $11 \%$ of the global demosponge diversity (Table 1). The distribution of the diversity at the higher taxonomic levels (Orders) found for the NEA/MED is similar to that found at the global scale (Fig. 2a, b). Overall, the Mediterranean is more species-rich than the Northeast Atlantic, harbouring 539 versus 480 species, respectively. The most speciose Mediterranean areas are the South coasts of Spain, France and Italy (CAT, GLI, LIG, cTYR), each harbouring over 230 shallow-water demosponge species. In the Northeast Atlantic the highest species-richness values were found in the North coast of Iberia (nIBE), the English Channel (CHL), and the Macaronesian archipelagos of the Canaries, Madeira (CAN) and Cape Verde (CAP), with over 160 species reported for each of these locations (Table 1).
Taxonomic distinctness among areas varied considerably (Table 1). The values of taxonomic distinctness of the Mediterranean assemblages were higher than the values seen in the Atlantic, with the exception of those located in the Lusitanian region (CAN, wIBE and CAP), which exhibited similar values to the Mediterranean. All Mediterranean locations except the Alboran Sea had AvTD above the mean and many were above the $95 \%$ upper limit of expectation (Fig. 3a). All of the Atlantic areas, except for those previously mentioned, exhibited AvTD values below the mean, and many localities (n, sNOR; SCO; IRI; CHL; FRA and nIBE) were found to be even below the lower limit of expectation (Fig. 3a).

When the Atlantic and Mediterranean areas were considered separately, we found that in the Atlantic only the west coast of Iberia and the Macaronesian archipelagos of the Canaries and Cape Verde exhibited a taxonomic distinctness above the $95 \%$ expectation limit. All other Northeast Atlantic areas revealed an AvTD below the mean, and several were close to and even below the lower expectation limit (Fig. 3b). The Mediterranean areas were more centred on the mean AvTD, and only the easternmost localities approached or rose above the upper limit. The Alboran Sea is the only Mediterranean locality whose assemblages fall at the lower limit of expectation (Fig. 3c).

The values of taxonomic distinctness of each area were found to be correlated with both modern $\left(R^{2}=0.5667 ; P<0.01\right)$ and historical values of SST $\left(R^{2}=0.7287 ; P<0.01\right)$, but more so with the latter (Fig. 4a, b). Note that for this analysis some areas could not be taken into account, either because the SST anomaly was so extreme that the sea had been covered in ice (e.g. off the coasts of Scotland and Norway), or because during times of lowered sea level the areas were totally emerged (e.g. the northern Adriatic and North Seas).

\section{Zoogeographical affinities}

The Bray-Curtis classification analysis revealed three main groups with further sub-structuring. Group I comprises the assemblages found in the north and easternmost section of the study area, with one subgroup with the localities of the Norwegian coasts (Ia) and another with the localities of the North Sea (Ib), each exhibiting a mere $20 \%$ average similarity with the remaining NEA and MED. Group II includes 
Table 1 Diversity estimates for each of 14 Northeast Atlantic (NEA) and 14 Mediterranean (MED) areas

\begin{tabular}{|c|c|c|c|c|c|c|}
\hline Area & Species & Genera & Families & Orders & $\operatorname{AvTD}\left(\Delta^{+}\right)$ & $\operatorname{VarTD}\left(\Lambda^{+}\right)$ \\
\hline \multicolumn{7}{|c|}{ Northeast Atlantic (NEA) } \\
\hline AZO & 95 & 51 & 35 & 11 & 92.42 & 266.4 \\
\hline CAP & 181 & 106 & 49 & 11 & 94.65 & 172.4 \\
\hline CAN & 163 & 89 & 50 & 13 & 94.85 & 190.5 \\
\hline wIBE & 135 & 71 & 39 & 10 & 94.70 & 182.9 \\
\hline nIBE & 171 & 83 & 44 & 10 & 92.66 & 216.4 \\
\hline FRA & 83 & 45 & 29 & 10 & 91.54 & 267.4 \\
\hline CHL & 167 & 77 & 38 & 12 & 91.11 & 278.3 \\
\hline $\mathrm{SCO}$ & 100 & 51 & 31 & 11 & 89.52 & 297.6 \\
\hline IRI & 107 & 55 & 31 & 11 & 91.86 & 270.0 \\
\hline wNSE & 34 & 25 & 20 & 9 & 93.23 & 254.9 \\
\hline sNSE & 40 & 25 & 17 & 7 & 91.99 & 312.4 \\
\hline sNOR & 119 & 60 & 32 & 10 & 90.97 & 257.6 \\
\hline wNOR & 92 & 51 & 30 & 10 & 92.40 & 236.7 \\
\hline nNOR & 81 & 47 & 28 & 10 & 92.04 & 244.8 \\
\hline \multicolumn{7}{|c|}{ Mediterranean Sea (MED) } \\
\hline ALB & 159 & 85 & 45 & 9 & 93.57 & 206.8 \\
\hline CAT & 236 & 114 & 52 & 13 & 94.41 & 217.9 \\
\hline ALG & 94 & 64 & 37 & 12 & 95.45 & 157.1 \\
\hline GLI & 226 & 114 & 56 & 13 & 94.58 & 199.6 \\
\hline LIG & 250 & 113 & 52 & 14 & 94.24 & 197.0 \\
\hline nTHY & 100 & 62 & 36 & 11 & 94.94 & 194.0 \\
\hline cTHY & 270 & 116 & 54 & 14 & 94.18 & 205.8 \\
\hline sTHY & 92 & 61 & 38 & 11 & 95.12 & 181.5 \\
\hline TUN & 120 & 63 & 40 & 13 & 94.32 & 212.4 \\
\hline nADR & 147 & 77 & 41 & 11 & 94.70 & 212.8 \\
\hline sADR & 154 & 85 & 46 & 13 & 95.12 & 190.5 \\
\hline ION & 166 & 92 & 52 & 13 & 94.98 & 180.3 \\
\hline $\mathrm{AEG}$ & 183 & 93 & 51 & 14 & 95.14 & 179.5 \\
\hline LEV & 91 & 59 & 35 & 13 & 95.58 & 167.3 \\
\hline Total NEA & 480 & 147 & 58 & 13 & 92.42 & 246.31 \\
\hline Total MED & 539 & 167 & 62 & 14 & 94.74 & 193.04 \\
\hline Total NEA/MED & 745 & 187 & 64 & 14 & 93.58 & 219.67 \\
\hline
\end{tabular}

For abbreviations see "Methods" section

the Lusitanian areas and it is further subdivided into the NW coast of Europe (IIa) and the Iberian coasts (IIb). Group III comprises all of the Mediterranean locations, as well as the Canaries and Cape Verde archipelagoes. This latter group is further divided in subgroups that represent the central, western and eastern Mediterranean (IIIa, IIIb and IIIc, respectively). The Azorean assemblage assumes an outlying position in relation to the Lusitanian region, with which it exhibits a $40 \%$ similarity, as do the assemblages of Alboran, Algeria, Canaries and Cape Verde in relation to the Mediterranean subgroups (Fig. 5). Similar structure and groupings were obtained from the nMDS for both species and genera presence/ absence (Fig. 6a, b).

The analysis of similarity percentages (SIMPER) showed that the MED areas exhibit an average pairwise similarity $(49.11 \%)$ higher than the NEA areas 

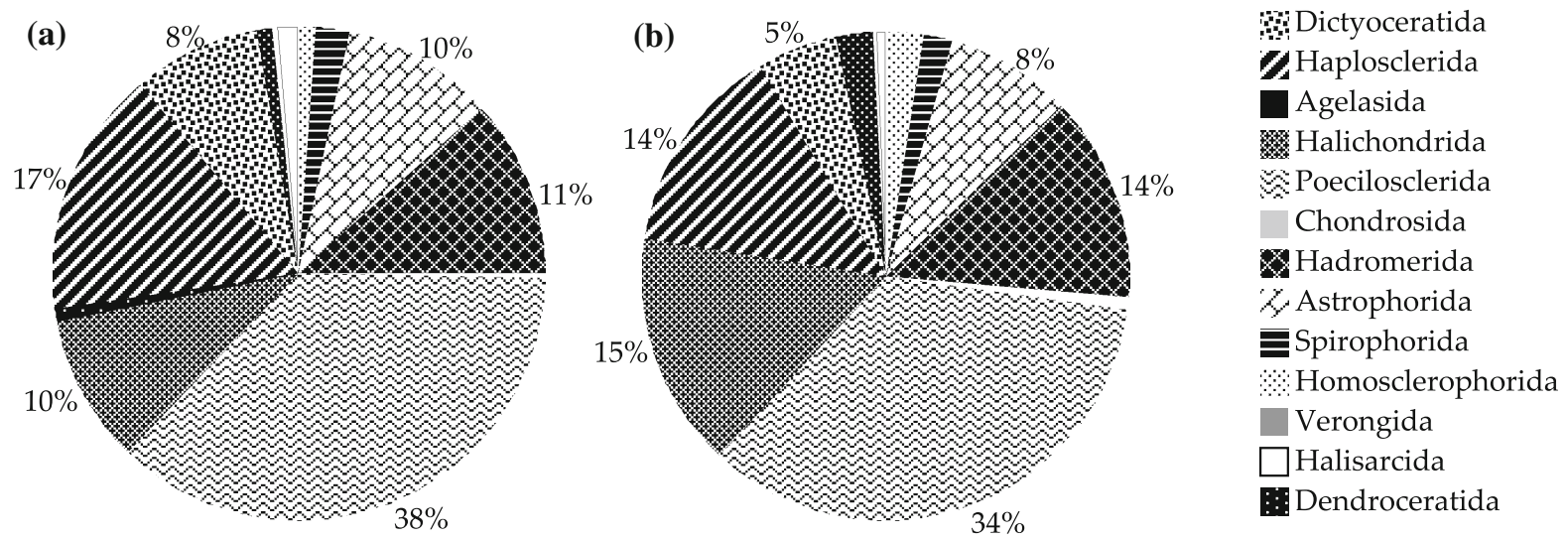

Fig. 2 Higher level (Order) taxonomic composition of the demosponge fauna at a global scale $(S=6,777$; WPD, Van Soest et al., 2009); b Northeast Atlantic and Mediterranean $(S=745$; this study)

(36.96\%), while NEA and MED are on average $72 \%$ dissimilar. A significant rank correlation was found between the biotic affinities among areas (BrayCurtis similarities) and the geographical distances separating these areas (Fig. 7; Spearman's $r_{\mathrm{S}}=0.767$; $P<0.01)$.

\section{Range and endemism}

Out of the total number of 745 species, 37\% were found to have an Atlanto-Mediterranean distribution, while $206(28 \%)$ and $265(36 \%)$ were found to be endemic to the Northeast Atlantic and to the Mediterranean, respectively. Overall, the Northeast Atlantic is composed of 206 Atlantic endemic (44\%) and 274 Atlanto-Mediterranean $(56 \%)$ species. Similar proportions were found for the species inhabiting the Mediterranean: 265 (49\%) are endemic to this enclosed Sea while $274(51 \%)$ also occur in the Atlantic. Regarding the geographical range of the Northeast Atlantic and the Mediterranean species, we found that single-area occurrences or narrow-ranged species account for $67 \%$ of the Northeast Atlantic fauna and $57 \%$ of the Mediterranean fauna, whereas a wide distribution range accounts for only a very small proportion of the fauna endemic to each of the basins (6 and 8\%, respectively) (Fig. 8a, b).

\section{Discussion}

There is growing scientific evidence that present-day biodiversity and biogeographical patterns are a result of both contemporary and historical climatic conditions. Uncovering and understanding these patterns is pivotal to predict both proximate and emergent ecological responses (e.g. changes in physiology, reproductive cycles, distributional shifts, changes in species composition, diversity and community structure, population dynamics and evolution) to the ongoing anthropogenically induced climate change (see Harley et al., 2006 for a review).

Diversity patterns of the Northeast Atlantic and Mediterranean sponge fauna

Harbouring over 700 species, the Northeast Atlantic and the Mediterranean appear to be a diversity hotspot for shallow-water demosponges, containing approximately $11 \%$ of the currently known demosponge species at a global scale (Van Soest et al., 2009). Although this value may result from a long-standing sponge taxonomic tradition in Europe, and because the true diversity of this group is estimated to harbour twice the current number of described species (approx. 7,000 demosponges, WPD, Van Soest et al., 2009), it still represents a remarkably rich sponge fauna, comparable only with regions such as the Caribbean, Australian Seas, or the Indo-West Pacific (see Van Soest, 1994). This species richness is even more remarkable if we take into account the fact that at least another 300 demosponge species are known to occur in this area but at greater depths (J.R. Xavier and R. Van Soest, unpublished data).

To understand the diversity patterns of the shallowwater sponge fauna found in the Northeast Atlantic 
Fig. 3 Taxonomic distinctness (AvTD or $\Delta^{+}$): a Northeast Atlantic and Mediterranean, b only Northeast Atlantic, and c only Mediterranean areas. The central line indicates mean $\Delta^{+}$(AvTD of the master list) while funnel lines constitute the $95 \%$ limits of the simulated $\Delta^{+}$ values. The points represent the AvTD values for each area plotted against the number of species
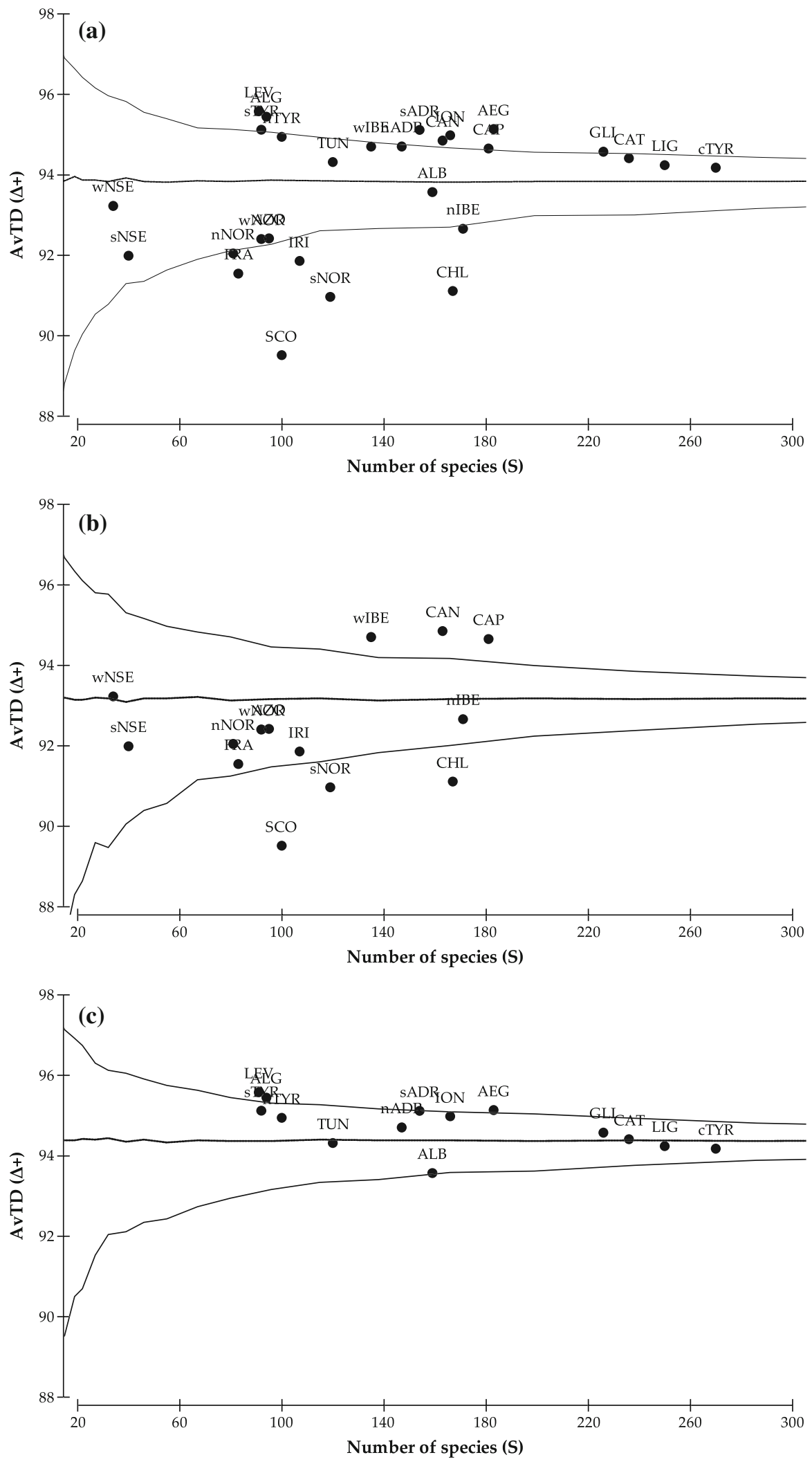

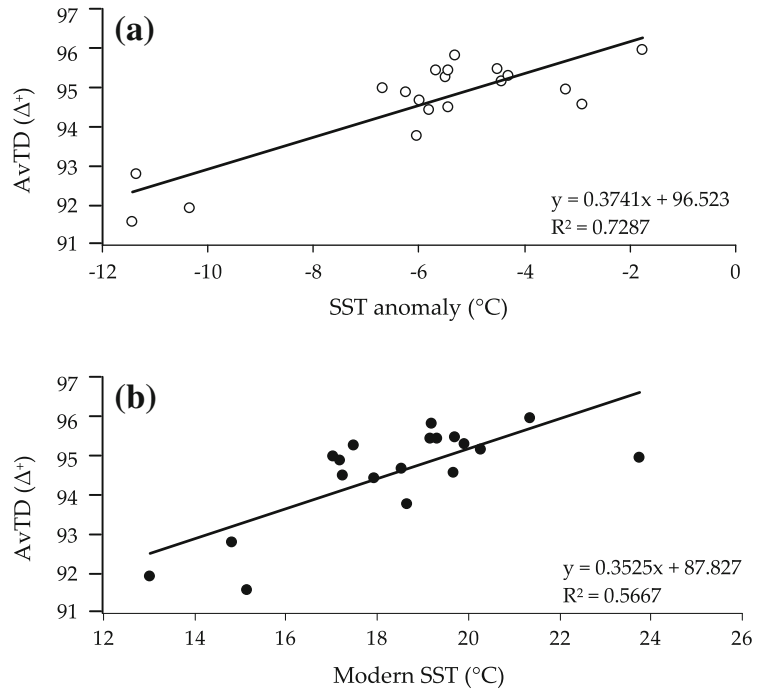

Fig. 4 Linear regression between taxonomic distinctness $\left(\right.$ AvTD or $\Delta^{+}$) and sea surface temperature (SST): a historical SST (Last Glacial Maximum-modern-time), and b moderntime SST

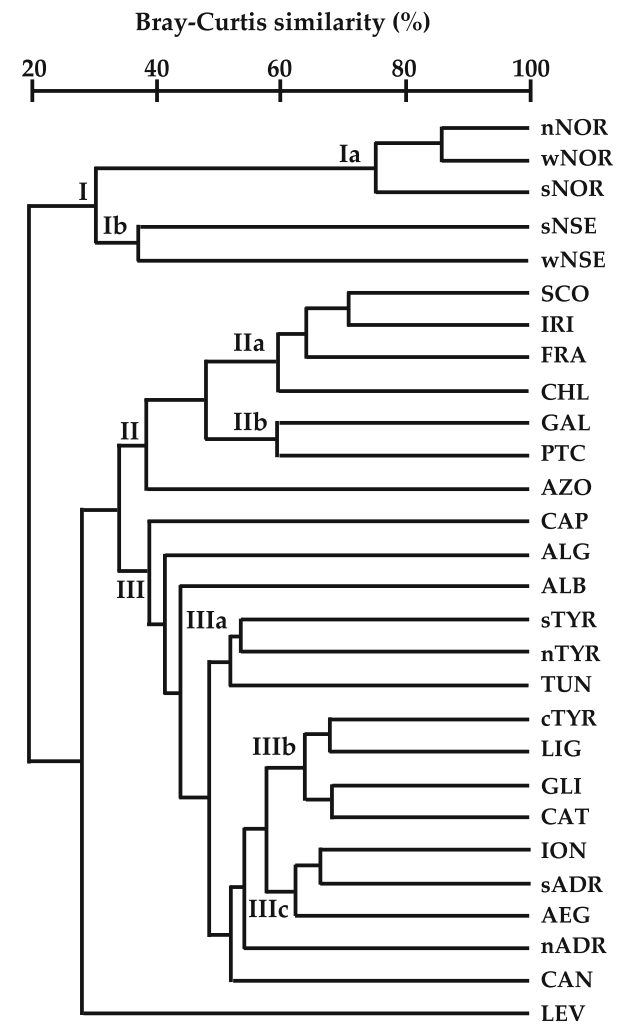

Fig. 5 Dendogram of hierarchical agglomerative clustering based on the Bray-Curtis similarity index. For area codes see "Methods" section and Mediterranean region, one must consider the paleo-history of these areas in the Mio-, Plio- and Pleistocene. The two most prominent events of this period were (i) the Messinian salinity crisis of the Mediterranean in the late Miocene (MSC, 5.96-5.33 Myr BP), and (ii) the Quaternary glacial-interglacial cycles that culminated in the LGM (30-19 kyr BP).

The MSC was a major desiccation of the Mediterranean basin caused by a tectonic uplift of the marine gateways between the Atlantic and Mediterranean (Hsü et al., 1973; Krijgsman et al., 1999; Rouchy \& Caruso, 2006). This event, considered one of the most dramatic episodes of the Cenozoic, resulted in a massive extinction of the Mediterranean marine fauna, except for some organisms that may have survived under brackish or hypersaline conditions. Once reopened, the connection to the Atlantic enabled a massive replenishment of the basin with Atlantic water and its fauna. As such, the present-day Mediterranean sponge fauna is of post-MSC assembly and composed of Atlantic (and a few Red Sea) immigrants, species that have evolved within the Mediterranean basin, along with a few Tethyan relics as suggested by previous authors (Maldonado \& Uriz, 1995; Pansini \& Longo, 2003).

The glaciations of the Pleistocene, and particularly the LGM, are known to have constituted the most influential events in shaping present-day distributions of terrestrial and aquatic biota, as a consequence of extinction, displacement and range-contraction, followed by range-expansion and re-colonization (Hewitt, 1996, 1999, 2000, 2004). During the LGM, the British and the Irish as well as the Scandinavian ice sheets advanced and covered large areas of northern Europe (Bowen et al., 2002; Clark \& Mix, 2002). The concurrent eustatic sea-level fluctuations that reached a nadir of $130 \mathrm{~m}$ below current level (Yokoyama et al., 2000; Lambeck \& Chappell, 2001; Lambeck et al., 2002) dramatically changed the contour of the European shores, exposing most of the North Sea Basin, part of the Bay of Biscay shelf and the northern Adriatic, along with some seamounts between the southwest coast of Portugal and Madeira island. In addition, there has been a strong decrease in SST (anomaly), which has differentially affected the various areas of the Atlanto-Mediterranean. Based on several paleoclimatic reconstructions, the maximum Atlantic SST anomaly during the LGM $\left(\approx 12^{\circ} \mathrm{C}\right.$ lower than today) was located at approximately $45^{\circ} \mathrm{N}$, 
Fig. 6 Non-metric MDS plots of the Northeast Atlantic and Mediterranean shallow-water demosponge assemblages based on a species and $\mathbf{b}$ genera increasingly dark shades join areas of increasing \% similarity (see scale bar) presence/absence. The
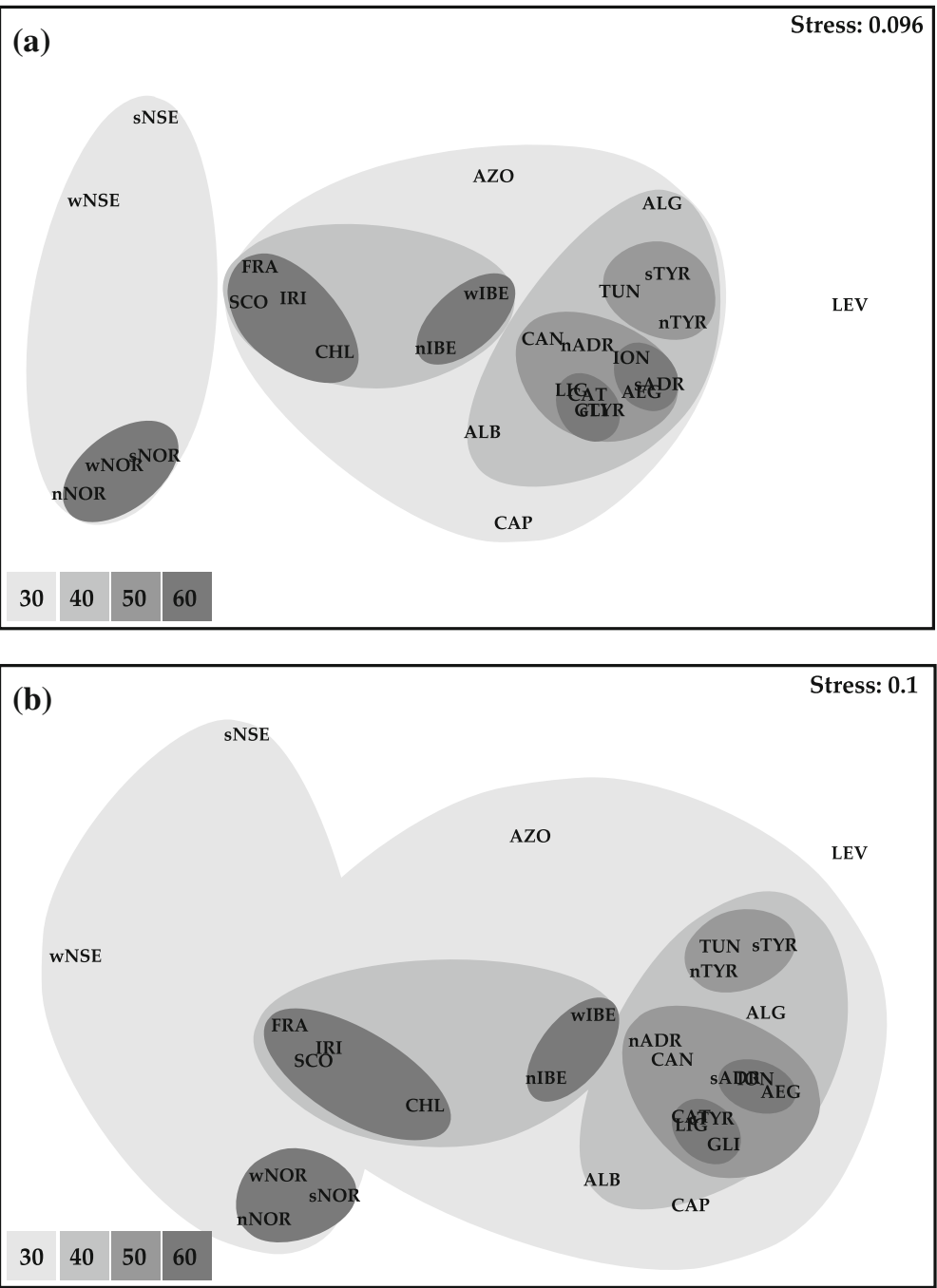

Fig. 7 Scatter plot of BrayCurtis similarities and pairwise geographical distances $(\mathrm{km})$ between the studied areas $(N=279$ pairwise comparisons). Spearman's $r_{\mathrm{S}}=0.767$; $P<0.01$

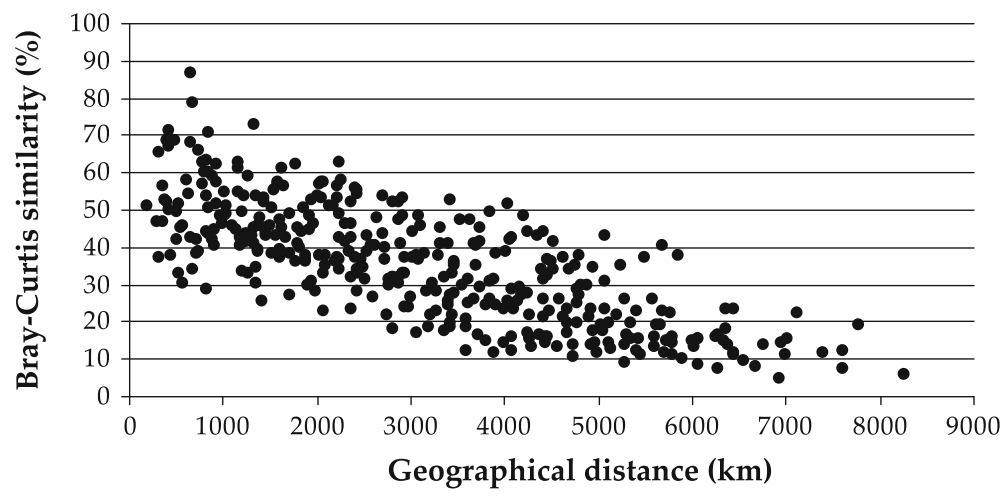

et al., 2003). In the Mediterranean, reconstructions of the SST at the LGM suggest an east-west temperature gradient of 9 and $6^{\circ} \mathrm{C}$ during glacial winter and glacial summer, respectively, with maximum SST anomalies steeply decreasing along the Portuguese coast down to the West African coast (including the Madeira and the Canary and Cape Verde islands), where SST's were slightly lower than the current ones (see Pflaumamm 

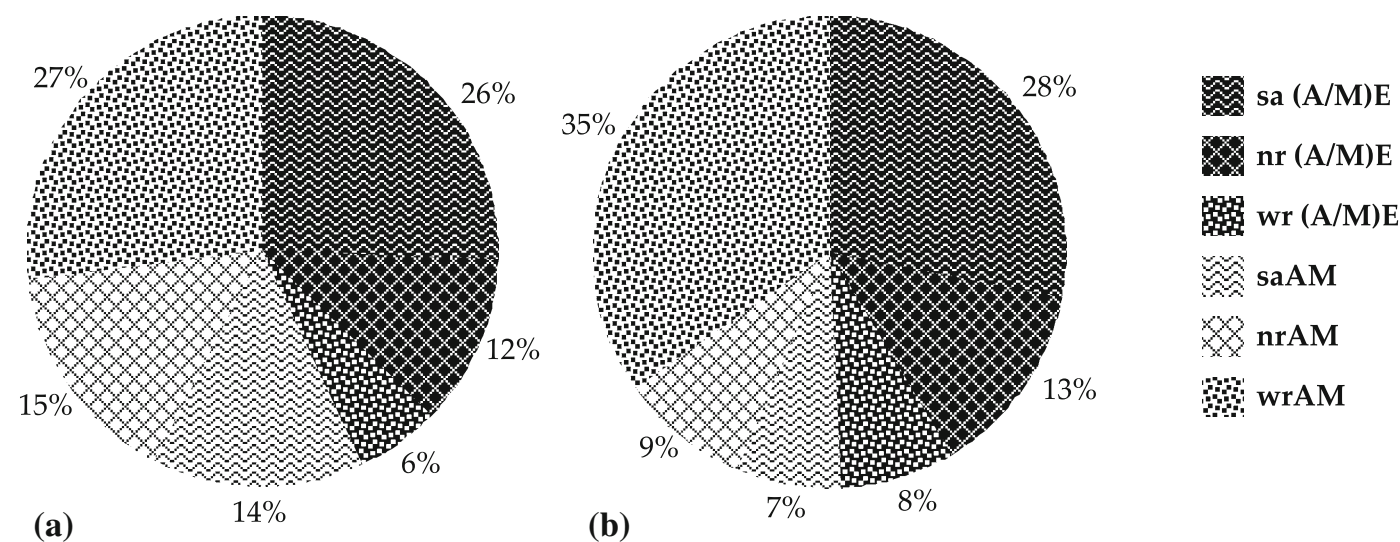

(b)

Fig. 8 Distribution range of the species in the a Northeast Atlantic $(S=480)$; b Mediterranean Sea $(S=539)$. $s a$ single-area occurrence, $n r$ narrow-range, $w r$ wide-range, $(A / M) E$ Atlantic or Mediterranean endemic, AM Atlanto-Mediterranean

$\left(11^{\circ} \mathrm{C}\right.$ lower than today) occurring along the northwestern coasts (Hayes et al., 2005) (Fig. 9).

Despite the massive extinction of its fauna during the MSC, the Mediterranean experienced more stable climatic conditions during the Pleistocenic glaciations than the Northeast Atlantic, which repeatedly lost a significant proportion of suitable marine habitat over relatively short periods of time. This relative stability for the Mediterranean over the past 5 Myr along with an on-going input of Atlantic shallow-water fauna, explains the higher present-day species richness (by about $12 \%$ ), as well as the taxonomic distinctness of this basin.

The N-S Atlantic and the NW-SE Mediterranean gradient of increasing taxonomic distinctness that we observed in our study seems to strongly correlate with the SST anomaly gradient of the LGM. For example, the largest shift in taxonomic distinctness, from above to below $95 \%$ expectation limits, occurs in the Northeast Atlantic between the North and West coasts of Iberia $\left(\operatorname{AvTD}_{\text {wIBE }}=94.70, \operatorname{AvTD}_{\text {nIBE }}=92.66\right)$, coinciding with the area where a shift from strong $\left(-11.4^{\circ} \mathrm{C}\right)$ to moderate $\left(-6.5^{\circ} \mathrm{C}\right)$ SST anomaly occurred (Fig. 9). Similarly, the eastern and southernmost areas of the Mediterranean Sea, which exhibit the highest AvTD values, coincide with areas where smaller SST anomalies occurred. Furthermore, due to the on- to offshore gradient of decreasing SST anomaly, the Macaronesian archipelagos displayed more stable environmental conditions throughout the glaciations (Pflaumamm et al., 2003), therefore serving as glacial refugia for populations and species. This is reflected in the high taxonomic-distinctness values of the Cape Verde and Canary islands (AvTD$\left.\mathrm{CAP}=94.65, \operatorname{AvTD}_{\mathrm{CAN}}=94.85\right)$, both above the $95 \%$ expectation. The apparent counter-pattern found for the Azores, which despite having suffered a smaller SST anomaly than the wIBE has a relatively low AvTD value, may be related to other factors such as geographical isolation.

Interglacial conditions began to become restored approximately $19 \mathrm{kyr} \mathrm{BP}$, with the retreat of the ice sheets, a rise in sea-level, increasingly warmer SST's, and the re-establishment of the sea surface circulation patterns. During this period, species are known to have expanded their ranges into previously glaciated areas at a pace compatible with their dispersal abilities (Hewitt, 1999). Thus, the northern latitude assemblages should be composed of re-colonizers expanding from southern refugia and potential cold-adapted species that could have sought refugia in deep-waters. The particularly high species richness observed along the coast of Norway, especially in the south, is probably an example of the latter phenomenon, where some groups (thus explaining the relatively low AvTD) could have found refugia in the deeper Norwegian trench (e.g. the Skagerrak with a maximum depth of $700 \mathrm{~m}$ ) or off the continental shelf. These species would have subsequently expanded their ranges to shallower water at the end of the LGM.

While some areas (e.g. nIBE, CHL) seem to have recovered their species richness, their assemblages remain taxonomically unbalanced (which is shown by their low AvTD and high varTD). Other more highlyimpacted and isolated areas such as the North Sea, have yet to recover their presumably richer pre-LGM 


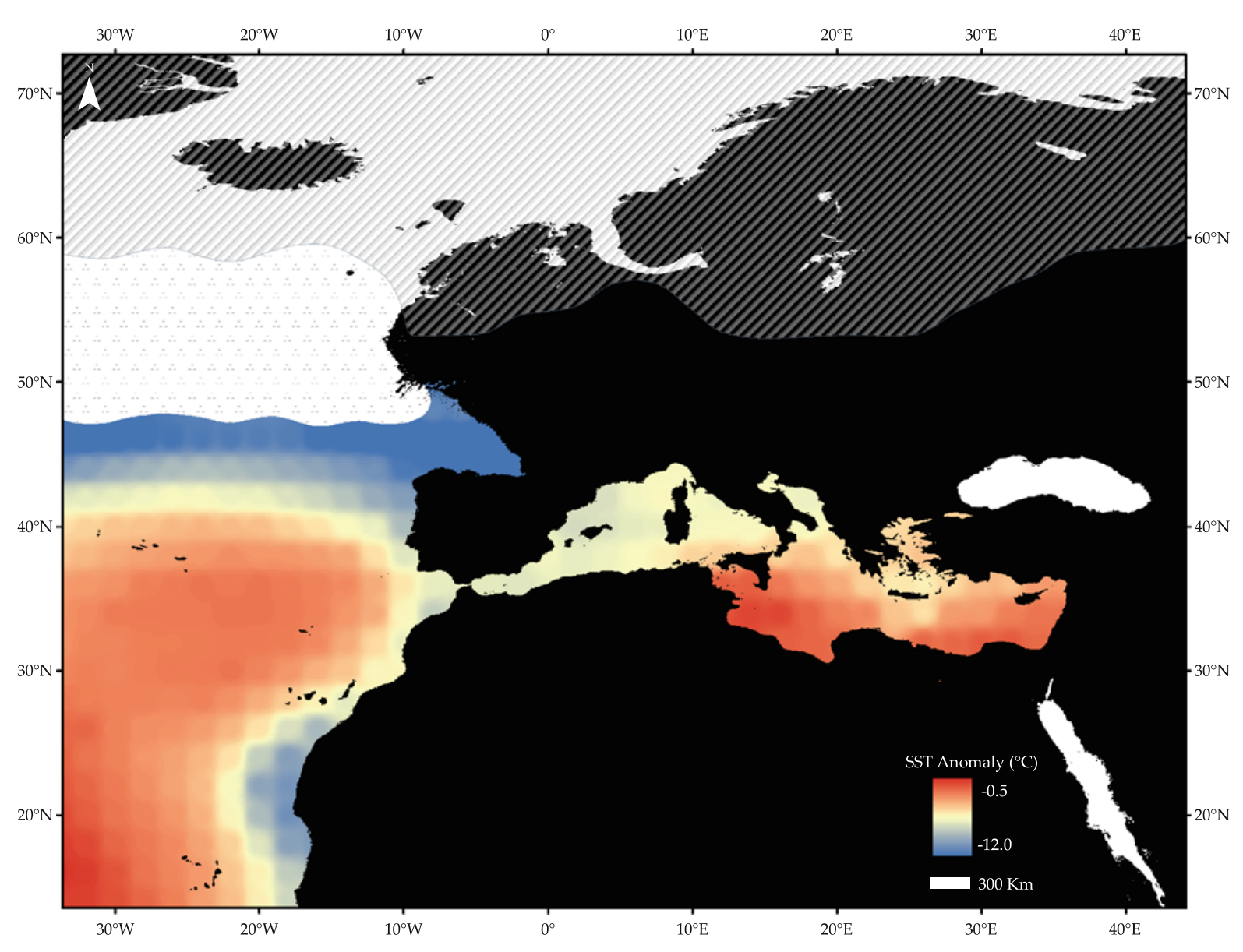

Fig. 9 Approximate representation of the Northeast Atlantic and Mediterranean at the Last Glacial Maximum (LGM; 21 kya). Coastlines extended to a $-130 \mathrm{~m}$ sea-level lowstand (bathymetric data from GEBCO $1 \mathrm{~min}$ grid). Shaded striped

sponge fauna, and their current assemblages appear to be the result of chance dispersals and human-mediated introductions (see Van Soest et al., 2007b).

The strong correlation between AvTD and SST values, although not necessarily implying causation, at least provides a plausible explanation for the influence of present and past climate on the regional sponge assemblages. Due to the intricate links between the different environmental factors (temperature, salinity, sea-level, ocean circulation), SST was used as a proxy in the present study. Yet, these and other factors, such as the area of rocky substrate at present and at LGM, summer maxima and winter minima in SST, distance to nearest potential refugia in both shallow and deeper water, cannot be ignored and should be further explored to better our understanding of sponge diversity patterns in this area. Furthermore, understanding areas represent permanent land and sea ice cover and dotted areas represent seasonal sea ice. Palaeoclimatic data from CLIMAP (1981)

the relationships between biological traits of individual species or groups and their ecological requirements, in addition to their responses to past climate, will prove essential in predicting future climate effects on marine biodiversity (see Bianchi, 2007).

The patterns found in our study at a meta-community scale are concordant with phylogeographic patterns observed for several marine taxa in the AtlantoMediterranean region (see review in Maggs et al., 2008). In these studies, gradients of genetic diversity and endemism were used to infer refugial areas for diverse marine organisms. While most studies have supported the southern refugia hypothesis for the Mediterranean, Iberian Peninsula and Macaronesian islands (e.g. Chevolot et al., 2006; Domingues et al., 2006, 2007a, b, 2008), others have shown that some populations may have persisted in northern periglacial 
refugia (e.g. Provan et al., 2005; Hoarau et al., 2007). In Porifera, the southern island refugium pattern has been observed for the poecilosclerid Phorbas fictitius (Xavier et al., 2010a).

\section{Zoogeographical affinities}

The zoogeographical groups found in our study are concordant with the overall geologic and oceanographic setting of the Atlanto-Mediterranean region, and are mostly consistent with the main provinces and eco-regions outlined in the MEOW classification system proposed by Spalding et al. (2007). The only exceptions that we found were the English Channel, Irish, and Celtic Seas that cluster in the Lusitanian Province, and the Canaries that group with the Mediterranean Sea.

The Northern European Seas province in the Atlantic, constituted by the North and Norwegian Seas (group I), is characterized by an impoverished cold-water fauna, which along with its geographic and oceanographic isolation, explains its low similarity (approximately 30\%) to the remaining NEA areas. The Lusitanian province (group II) comprises all of the western European coastal areas running from the coast of Portugal northwards to the coast of Scotland. Within this group, the northernmost areas (subgroup IIa) fall under the influence of the North Atlantic Current, whereas the Iberian Peninsula (subgroup IIb) is additionally influenced by the Portugal coastal current, which flows southward in the summer and polewards in the winter (Ambar \& Fiúza, 1994; Reverdin et al., 2003).

In contrast to the complex surface circulation of the NEA, the more enclosed Mediterranean circulation explains the highest mean similarities that are found among its areas in comparison to the Atlantic. Nevertheless, three subgroups (IIIa-c) separating the western, central and eastern Mediterranean assemblages have been found. The low similarity and outlying position of the Alboran and Algerian assemblages to the remaining western Mediterranean is consistent with the well-known hydrographical barrier of the Almeria-Oran front, which is associated with the circulation in two anticyclonic gyres of the inflowing Atlantic water (Tintore et al., 1988).

We cannot, however, explain the closer similarity between westernmost (subgroup IIIb) and easternmost (subgroup IIIc) Mediterranean areas, whose faunas would have to have been connected through the Siculo-Tunisian Strait, but exhibit a surprisingly lower similarity to this area. The low similarity found between the Levantine basin and the remaining areas is most likely due to a combination of our poor knowledge of the fauna in this area along with an influence of species from the Red Sea entering the Mediterranean through the Suez Canal.

Our observations confirmed the strong affinity of the Mauritanian (Canaries) and Senegalian faunas (Cape Verde) with those of the westernmost Mediterranean (Alboran, Catalunya, Algeria) reported by previous authors (e.g. Van Soest, 1993b; Maldonado \& Uriz, 1995; Carballo et al., 1997). This affinity has been suggested to be the result of a past inflow of Senegalian-Mauritanian elements into the Mediterranean (Maldonado \& Uriz, 1995; Pansini \& Longo, 2003) and may reflect a pattern of post-glacial rangeexpansion of species from southern island refugia. Alternatively this similarity could have resulted from the parallel dispersal of species from the Iberian Peninsula both into the Canary/Cape Verde and western Mediterranean through the Portugal current system.

Both geographical distance and oceanographic currents seem to constitute important factors shaping the zoogeographical affinities of the sponge fauna among the different areas, as is to be expected since this taxonomic group relies on currents for the transport of its poorly dispersing larvae.

Range, endemism and implications

for conservation

Despite their ecological and biotechnological relevance, sponges have thus far received little if any attention from a conservation viewpoint, in contrast to other lower metazoan groups such as corals. This is likely due to a yet unacknowledged importance that sponges play on ecosystem functioning and the false perception that sponge species are widely distributed, which in turn is a result of overconservative systematic traditions and morphological stasis of some groups. However, since the advent of molecular techniques this later view has begun slowly but steadily to change as a growing number of allegedly cosmopolitan species are being shown to constitute 
complexes of cryptic species (Klautau et al., 1999; Xavier et al., 2010b). In an assessment of global distribution patterns of demosponges, Van Soest (1994) found that over $70 \%$ of all species were confined to one of the 35 areas in which he divided the globe. These restricted distributions have been corroborated in the present study as we provided further evidence for the small distribution range of most sponge species. In fact, more than half of the total Northeast Atlantic and Mediterranean species occur in only 1-3 out of the 28 considered areas. Even more striking is that this level of endemism seems to hold true over much smaller spatial scales. Examining the diversity patterns of the sponge fauna of several reefs within a $50 \mathrm{~km}$ radius in eastern Australia, Hooper \& Kennedy (2002) found that $60 \%$ of all species occurred on a single reef. These observations suggest that populations are mostly sustained by local recruitment of their larvae.

Due to this high level of endemism and the important roles played by this taxonomic group in ecosystem functioning, such as in bentho-pelagic coupling, substrate dynamics or its biotic interactions (see review in Bell, 2008), sponges should in the future be consistently represented in monitoring programmes and conservation strategies. Furthermore, given the growing commercial interest in this taxonomic group due to its biotechnological potential in pharmaceutics (Munro et al., 1999), further advancement in the aquaculture of sponges, and total synthesis of discovered compounds, should be promoted to avoid depletion of the existing populations.

Acknowledgments The authors wish to thank Robert Clarke, Paul Sommerfield and Ray Gorley for helpful suggestions on data analysis during the PRIMER-E workshop held in Plymouth. We further thank Hans Tore Rapp, Bernard Picton, Claire Goodwin and Mario de Kluijver for data sharing and insightful discussions regarding species distributions in their study areas. We are also grateful to Steph Menken, Cleve Hicks and Nuno Curado for constructive comments on an earlier version of this manuscript and the latter for building Figs. 1 and 9. This study was funded by Fundação para a Ciência e Tecnologia (FCT-Portugal; Grants Nos. SFRH/BD/16024/2004 and SFRH/BPD/62946/2009) as part of J. R. Xavier research on the biodiversity, ecology and evolution of both shallow-water and deep-sea sponge fauna of the Atlanto-Mediterranean area.

Open Access This article is distributed under the terms of the Creative Commons Attribution Noncommercial License which permits any noncommercial use, distribution, and reproduction in any medium, provided the original author(s) and source are credited.

\section{References}

Ackers, R. G., D. Moss \& B. E. Picton, 1992. Sponges of the British Isles (Sponge V): A Colour Guide and Working Document. Marine Conservation Society: 175 pp.

Ambar, I. \& A. Fiúza, 1994. Some features of the Portugal Current System: a poleward slope undercurrent, an upwelling-related summer southward flow and an autumnwinter poleward coastal surface current. In Katsaros, K., A. Fiúza \& I. Ambar (eds), Proceedings of the Second International Conference on Air-Sea Interaction and on Meteorology and Oceanography of the Coastal Zone. American Meteorological Society, Lisbon: 286-287.

Araújo, M. B., D. Nogués-Bravo, J. A. F. Diniz-Filho, A. M. Haywood, P. J. Valdes \& C. Rahbek, 2008. Quaternary climate changes explain diversity among reptiles and amphibians. Ecography 31: 8-15.

Bell, J. J., 2008. The functional roles of marine sponges. Estuarine, Coastal and Shelf Science 79: 341-353.

Bell, J. J. \& D. K. A. Barnes, 2000. A sponge diversity centre within a marine island. Hydrobiologia 440: 55-64.

Bianchi, C. N., 2007. Biodiversity issues for the forthcoming tropical Mediterranean Sea. Hydrobiologia 580: 7-21.

Borley, H. J. H., 1931. Some additions to the sponge fauna of Plymouth. Journal of the Marine Biological Association of the United Kingdom 17: 839-846.

Borojevic, R., L. Cabioch \& C. Lévi, 1968. Inventaire de la faune marine de Roscoff: Spongiaires. Cahiers de Biologie Marine 9: 1-44.

Boury-Esnault, N. \& M. T. Lopes, 1985. Les Démosponges littorales de l'archipel des Açores. Annales de l'Institute Océanographique 61: 149-225.

Bowen, D. Q., F. M. Phillips, A. M. McCabe, P. C. Knutz \& G. A. Sykes, 2002. New data for the Last Glacial Maximum in Great Britain and Ireland. Quaternary Science Reviews 21: 89-101.

Burton, M., 1930. Additions to the sponge fauna at Plymouth. Journal of the Marine Biological Association of the United Kingdom 16: 489-507.

Burton, M., 1957. Phylum Porifera. In Wilson, D. P. (ed.), Plymouth Marine Fauna, 3rd ed. Marine Biological Association of the United Kingdom, Plymouth: 26-36.

Burton, M., 1963. Porifera. In Bruce, J. R., J. S. Colman \& N. S. Joes (eds), Marine Fauna of the Isle of Man and its Surrounding Seas. Memoir No. 36. Liverpool University Press, Liverpool: 42-47.

Cabioch, L., 1968. Contribution à la conaissance de la fauna des spongiaires de la manche occidentale. Démosponges de la région de Roscoff. Cahiers de Biologie Marine 9: 211-246.

Cabioch, L., 1973. Additions a l'inventaire de la faune marine de roscoff: Spongiaires. Travaux Station Biologique Roscoff 31: 5-6.

Cabioch, L. \& R. Glaçon, 1975. Distribution des peuplements benthiques en Manche orientale, de la baie de Somme au Pas de Calais. Compte Rendu de l'Académie des Sciences de Paris série D 280: 491-494.

Carballo, J. L., S. Naranjo \& J. C. Garcia-Gomez, 1997. Where does the Mediterranean Sea begin? Zoogeographical affinities of the littoral sponges of the Straits of Gibraltar. Journal of Biogeography 24: 223-232. 
Chevolot, M., G. Hoarau, A. Rijnsdorp, W. Stam \& J. Olsen, 2006. Phylogeography and population structure of thornback rays (Raja clavata L., Rajidae). Molecular Ecology 15: 3693-3705.

Clark, P. U. \& A. C. Mix, 2002. Ice sheets and sea level of the Last Glacial Maximum. Quaternary Science Reviews 21: $1-7$.

Clarke, K. R. \& R. N. Gorley, 2006. PRIMER v6: User Manual/ Tutorial. PRIMER-E, Plymouth.

Clarke, K. R. \& R. M. Warwick, 1998. A taxonomic distinctness index and its statistical properties. Journal of Applied Ecology 35: 523-531.

Clarke, K. R. \& R. M. Warwick, 1999. The taxonomic distinctness measure of biodiversity: weighting of step lengths between hierarchical levels. Marine Ecology Progress Series 184: 21-29.

Clarke, K. R. \& R. M. Warwick, 2001a. Change in Marine Communities: An Approach to Statistical Analysis and Interpretation, 2nd ed. PRIMER-E, Plymouth.

Clarke, K. R. \& R. M. Warwick, 2001b. A further biodiversity index applicable to species lists: variation in taxonomic distinctness. Marine Ecology Progress Series 216: 265-278.

CLIMAP Project Members, 1976. The surface of the ice-age earth. Science 191: 1131-1144.

CLIMAP Project Members, 1981. Seasonal Reconstruction of the Earths Surface at the Last Glacial Maximum. Geological Society of America, Map and Chart Series, 36.

CLIMAP Project Members, 1984. The last interglacial ocean. Quaternary Research 21: 123-224.

Cristobo, F. J., 1997. Esponjas del Orden Poecilosclerida (Porifera: Demospongiae) de la Ría de Ferrol (NW de España). $\mathrm{PhD}$ thesis, Universidad de Santiago de Compostela.

Cruz, T., 1980. Contribucion al estudio de los espongiarios de las Islas Canarias. Demosponjas (Homosclerophorida, Astrophorida y Hadromerida) del litoral de Tenerife. Memoria para aspirar al grado de licenciado, Universidad de La Laguna.

Cruz, T., 1984. Espongiarios. In Estudio del Bentos Marino del Archipielago Canario. Catalogo preliminar de los invertebrados marinos bentonicos de Canarias.

Cruz, T., 2002. Esponjas Marinas de Canarias. Banco de datos de Biodiversidad de Canarias. Gobierno de Canarias: $258 \mathrm{pp}$.

Cruz, T. \& J. J. Bacallado, 1982. Contribucion al conocimiento de los espongiarios de las Islas Canarias. I - Demosponjas Homosclerophorida y Astrophorida del Litoral de Tenerife. Boletin del Instituto Espanol de Oceanografia 6: 75-87.

Cruz, T. \& J. J. Bacallado, 1983. Esponjas perforantes (Porifera, Clionidae) de Tenerife, Islas Canarias. Vieraea 12: 37-48.

Cruz, T. \& J. J. Bacallado, 1984a. Contribucion al conocimiento de los espongiarios de las Islas Canarias. II - Demosponjas Hadromerida del Litoral de Tenerife. Servicio Publicaciones Universidad La Laguna: 63-73.

Cruz, T. \& J. J. Bacallado, 1985a. Contribucion al conocimiento de los espongiarios de las Islas Canarias: demosponjas de los fondos de Dendrophyllia ramea en Tenerife. Anales Facultad de Ciencias 10: 71-98.

Cruz, T. \& J. J. Bacallado, 1985b. Introduccion a los poblamientos de espongiarios de las Islas Canarias. Proceedings of the IV Simposio Iberico Bentos Marino: 141-150. de Voogd, N. J. \& D. F. R. Clearly, 2007. Relating species traits to environmental variables in Indonesian coral reef sponge assemblages. Marine \& Freshwater Research 58: 240-249.

de Voogd, N. J., D. F. R. Cleay, B. W. Hoeksema, A. Noor \& R. W. M. Van Soest, 2006. Sponge beta diversity in the Spermonde Archipelago, SW Sulawesi, Indonesia. Marine Ecology Progress Series 309: 131-142.

De Weerdt, W. \& R. W. M. Van Soest, 1986. Marine shallowwater Haplosclerida (Porifera) from the South-Eastern part of the North Atlantic Ocean. Zoologische Verhandelingen 225: 1-49.

Descatoire, A., 1966. Sur quelques Démosponges de l'Archipel de Glénan. Cahiers de Biologie Marine 7: 231-246.

Descatoire, A., 1969. Les peuplements sessiles de l'Archipel de Glénan de l'infralittoral rocheux. II. Notes systématiques a propos de l'inventaire des Spongiaires. Vie et Millieu 20: 9-30.

Domingues, V. S., R. S. Santos, A. Brito \& V. C. Almada, 2006. Historical population dynamics and demography of the eastern Atlantic pomacentrid Chromis limbata (Valenciennes, 1833). Molecular Phylogenetics and Evolution 40: 139-147.

Domingues, V. S., R. S. Santos, A. Brito, M. Alexandrou \& V. C. Almada, 2007a. Mitochondrial and nuclear markers reveal isolation by distance and effects of Pleistocene glaciations in the Northeastern Atlantic and Mediterranean populations of the white seabream (Diplodus sargus, L.). Journal of Experimental Marine Biology and Ecology 346: 102-113.

Domingues, V. S., C. Faria, S. Stefanni, R. S. Santos, A. Brito \& V. C. Almada, 2007b. Genetic divergence in the AtlanticMediterranean Montagu's blenny, Coryphoblennius galerita (Linnaeus 1758) revealed by molecular and morphological characters. Molecular Ecology 16: 3592-3605.

Domingues, V. S., S. Stefanni, A. Brito, R. S. Santos \& V. C. Almada, 2008. Phylogeography and demography of the Blenniid Parablennius parvicornis and its sister species $P$. sanguinolentus from the Northeastern Atlantic Ocean and the western Mediterranean Sea. Molecular Phylogenetics and Evolution 46: 397-402.

Ferrer-Hernández, F., 1914. Esponjas del Cantabrico. Parte 2. III. Myxospongida. IV. Tetraxonida. V. Triaxonida. Trabajos del Museo Nacional de Ciencias Naturales 17: $1-46$.

Ferrer-Hernández, F., 1918. Esponjas del litoral de Asturias. Trabajos del Museo Nacional de Ciencias Naturales 36: $1-39$.

Ferrer-Hernández, F., 1922. Más datos para el conocimiento de las esponjas de las costas españolas. Boletin de Pescas 7: 247-272.

Hanitsch, R., 1895. Notes on a collection of sponges from the west coast of Portugal. Transactions Liverpool Biological Society 9: 205-219.

Harley, C. D. G., A. R. Hughes, K. M. Hultgreen, B. G. Miner, C. J. B. Sorte, C. S. Thornber, L. F. Rodriguez, L. Tomanek \& S. L. Williams, 2006. The impacts of climate change in coastal marine systems. Ecology Letters 9: 228-241.

Hayes, A., M. Kucera, N. Kallel, L. Sbaffi \& E. J. Rohling, 2005. Glacial Mediterranean Sea surface temperatures based on planktonic foraminiferal assemblages. Quaternary Science Reviews 24: 999-1016. 
Hewitt, G. M., 1996. Some genetic consequences of ice ages, and their role in divergence and speciation. Biological Journal of the Linnean Society 58: 247-276.

Hewitt, G. M., 1999. Post-glacial re-colonization of European biota. Biological Journal of the Linnean Society 68: 87-112.

Hewitt, G. M., 2000. The genetic legacy of the Quaternary Ice Ages. Nature 405: 907-913.

Hewitt, G. M., 2004. Genetic consequences of climatic oscillations in the Quaternary. Philosophical Transactions Royal Society B 359: 183-195.

Hiscock, K., S. Stone \& J. D. George, 1984. The marine fauna of Lundy: Porifera (Sponges). Report of the Lundy Field Society 34: 16-35.

Hoarau, G., J. A. Coyer, J. H. Veldsink, W. T. Stam \& J. L. Olsen, 2007. Glacial refugia and recolonization pathways in the brown seaweed Fucus serratus. Molecular Ecology 16: 3606-3616.

Hooper, J. N. A. \& J. A. Kennedy, 2002. Small-scale patterns of sponge biodiversity (Porifera) on Sunshine Coast reefs, eastern Australia. Invertebrate Systematics 16: 637-653.

Hooper, J. N. A. \& R. W. M. Van Soest, 2002. Systema Porifera: A Guide to the Classification of Sponges. Kluwer Academic/Plenum Publishers, New York.

Hsü, K. J., W. B. F. Ryan \& M. B. Cita, 1973. Late Miocene desiccation. Nature 242: 240-244.

Jansson, R., 2003. Global patterns in endemism explained by past climatic change. Proceedings of the Royal Society London B 270: 583-590.

Johnson, J. Y., 1899. Notes on some sponges belonging to the Clionidae obtained at Madeira. Journal of the Royal Microscopical Society 9: 461-463.

Kefalas, E. \& J. Castritsi-Catharios, 2007. Taxonomy of some sponges (Porifera: Demospongiae) collected from the Aegean Sea and description of a new species. Journal of the Marine Biological Association of the United Kingdom 87: 1527-1538.

Kefalas, E., G. Tsirtsis \& J. Castritsi-Catharios, 2003. Distribution and ecology of Demospongiae from the circalittoral of the islands of the Aegean Sea (Eastern Mediterranean). Hydrobiologia 499: 125-134.

Klautau, M., C. A. M. Russo, C. Lazoski, N. Boury-Esnault, J. P. Thorpe \& A. M. Solé-Cava, 1999. Does cosmopolitanism result from overconservative systematics? A case study using the marine sponge Chondrilla nucula. Evolution 53: 1414-1422.

Krijgsman, W., F. J. Hilgen, I. Raffi, F. J. Sierro \& D. S. Wilson, 1999. Chronology, causes and progression of the Messinian salinity crisis. Nature 400: 652-655.

Lambeck, K. \& J. Chappell, 2001. Sea level change through the last glacial cycle. Nature 292: 679-686.

Lambeck, K., T. M. Esat \& E. K. Potter, 2002. Links between climate and sea levels for the past three million years. Nature 419: 199-206.

Lévi, C., 1950. Remarques sur la faune des Spongiaires de Roscoff. Archives de Zoologie expérimentale et générale 87: 10-21.

Lévi, C. \& J. Vacelet, 1958. Éponges récoltées dans l'Atlantique Oriental par le "Président Théodore Tissier" (1955-1956). Recueil des Travaux de l'Institut des Pêches maritimes 22: 225-246.
Lopes, M. T., 1989. Demosponjas intertidais da Costa Portuguesa. $\mathrm{PhD}$ thesis, Universidade de Lisboa.

Lopes, M. T., 1995. Littoral sponges from Selvagens Islands. Boletim do Museu Municipal do Funchal 4: 387-394.

Lopes, M. T. \& N. Boury-Esnault, 1981. Contribution a la connaissance des eponges cornees de la cote de l'Arrabida et de l'Algarve. Arquivos do Museu Bocage 1: 95-109.

Maggs, C. A., R. Castilho, D. Foltz, C. Henzler, M. T. Jolly, J. Kelly, J. Olsen, K. E. Perez, W. Stam, R. Vainola, F. Viard \& J. Wares, 2008. Evaluating signatures of glacial refugia for North Alantic benthic marine taxa. Ecology 89: 108-122.

Maldonado, M., 2006. The ecology of sponge larvae. Canadian Journal of Zoology 84: 175-194.

Maldonado, M. \& M. J. Uriz, 1995. Biotic affinities in a transitional zone between the Atlantic and the Mediterranean: a biogeographical approach based on sponges. Journal of Biogeography 22: 89-110.

Mariani, S., M. J. Uriz \& X. Turon, 2005. The dynamics of sponge larvae assemblages from northwestern Mediterranean nearshore bottoms. Journal of Plankton Research 27: 249-262.

Mariani, S., M. J. Uriz, X. Turon \& T. Alcoverro, 2006. Dispersal strategies in sponge larvae: integrating the life history of larvae and the hydrologic component. Oecologia 149: 174-184.

Moss, D. L., 1992. A summary of the Porifera collected during "Expedition Azores 1989". Arquipélago, Life and Earth Sciences 10: 45-53.

Munro, M. H. G., J. W. Blunt, E. J. Dumdei, S. J. H. Hickford, R. E. Lill, S. Li, C. N. Battershill \& A. R. Duckworth, 1999. The discovery and development of marine compounds with pharmaceutical potential. Journal of Biotechnology 70: 15-25.

Mustapha, K. B., S. Zarrouk, A. Souissi \& A. El Abed, 2003. Diversite des demosponges Tunisiennes. Bulletin Institut National Sciences et Technologie de la Mer de Salammbô 30: $55-78$.

Naveiro, A., 2002. Poriferos de la costa da Arrábida (Portugal): Classe Demospongiae. Memoria para optar al grado de licenciado, Universidad de Santiago de Compostela.

Pansini, M. \& C. Longo, 2003. A review of the Mediterranean Sea sponge biogeography with, in appendix, a list of the demosponges hitherto recorded from this sea. Biogeographia 24: 59-90.

Patarnello, T., F. M. A. Volckaert \& R. Castilho, 2007. Pillars of Hercules: is the Atlantic-Mediterranean transition a phylogeographic break? Molecular Ecology 16: 4426-4444.

Pestana, R., 2002. Sistemática e ecologia de esponjas de substratos rochosos marinhos verticais e inclinados da costa Sul da Madeira. Tese de licenciatura, Universidade da Madeira.

Pflaumamm, U., M. Sarnthein, M. Chapman, L. d'Abreu, B. Funnell, M. Huels, T. Kiefer, M. Maslin, H. Schulz, J. Swallow, S. van Kreveld, M. Vautravers, E. Vogelsang \& M. Weinelt, 2003. Glacial North Atlantic: sea surface conditions reconstructed by GLAMAP 2000. Paleoceanography 18: 10-28.

Picton, B. E. \& C. Goodwin, 2007. Sponge biodiversity of Rathlin Island, Northern Ireland. Journal of the Marine Biological Association of the United Kingdom 87: 1441-1458. 
Pires, F., 2007. Padrões de distribuição e taxonomia para os Porifera da região central do Algarve. Tese de mestrado, Universidade do Algarve.

Preciado, I., 2002. Desmosponjas litorales del entorno de la Isla de Mouro (Santander, Mar Cantábrico): Taxonomia y Ecologia. PhD thesis, Facultad de Ciencias de la Universidad Autónoma de Madrid, Spain.

Provan, J., R. Wattier \& C. Maggs, 2005. Phylogeographic analysis of the red seaweed Palmaria palmata reveals a Pleistocene marine glacial refugium in the English Channel. Molecular Ecology 14: 793-803.

Reverdin, G., P. P. Niiler \& H. Valdimarsson, 2003. North Atlantic Ocean surface currents. Journal of Geophysical Research 108(C1): 3002.

Riesgo, A. \& M. Maldonado, 2008. Differences in reproductive timing among sponges sharing habitat and thermal regime. Invertebrate Biology 127: 357-367.

Rouchy, J. M. \& A. Caruso, 2006. The Messinian salinity crisis in the Mediterranean basin: a reassessment of the data and an integrated scenario. Sedimentary Geology 188: 35-67.

Samaai, T., 2006. Biodiversity "hotspots", patterns of richness and endemism, and distribution of marine sponges in South Africa based on actual and interpolation data: a comparative approach. Zootaxa 1358: 1-37.

Sarà, M. \& J. Vacelet, 1973. Écologie des Démosponges. In Grassé, P. (ed.), Traité de Zoologie, Spongiaires. Masson et Cie, Paris: 462-576.

Solórzano, M. R., 1991. Inventario dos Poríferos do Litoral Galego (Porifera). Caderno da Área de Ciencias Biolóxicas 7: 1-54.

Spalding, M. D., H. E. Fox, G. R. Aleen, N. Davidson, Z. A. Ferdaña, M. Finlayson, B. Halpern, M. A. Jorge, A. Lombana, S. A. Lourie, K. D. Martin, E. McManus, J. Molnar, C. A. Recchia \& J. Robertson, 2007. Marine ecoregions of the world: a bioregionalization of coastal and shelf areas. BioScience 57: 573-583.

Tendal, O. S., T. Brattegard \& H. T. Rapp, 2001. Phylum Porifera. In Brattegard, T. \& T. Holthe (eds), Distribution of Marine, Benthic Macro-organisms in Norway. A Tabulated Catalogue. Research Report for DN 2001-3. Directorate for Nature Management: 36-51.

Tintore, J., P. E. La Violette, I. Blade \& A. Cruzado, 1988. A study of an intense density front in the Eastern Alboran Sea: the Almeria-Oran front. Journal of Physical Oceanography 18: 1384-1397.

Topsent, E., 1892. Contribution á l'étude des Spongiaires de l'Atlantique Nord (Golfe de Gascogne, Terre-Neuve, Açores). Résultats des Campagnes Scientifiques accomplies par le Prince Albert I Monaco 2: 1-165.

Topsent, E., 1899. Documents sur la faune des Spongiaires des côtes de Belgique. Archives de Biologie 16: 105-115.

Topsent, E., 1904. Spongiaires des Açores. Résultats des Campagnes Scientifiques accomplies par le Prince Albert I Monaco 25: 1-280.

Topsent, E., 1928. Spongiaires de l'Atlantique et de la Méditerranée provenant des croisières de Prince Albert 1er de Monaco. Résultats des Campagnes Scientifiques accomplies par le Prince Albert I Monaco 74: 1-376.

Uriz, M. J., X. Turon \& S. Mariani, 2008. Ultrastructure and dispersal potential of sponge larvae: tufted versus evenly ciliated parenchymellae. Marine Ecology 29: 280-297.
Vacelet, J., G. Bitas, S. Carteron, H. Zibrowius \& T. Perez, 2007. Five new sponge species (Porifera: Demospongiae) of subtropical or tropical affinities from the coast of Lebanon (eastern Mediterranean). Journal of the Marine Biological Association of the United Kingdom 87: 1539-1552.

Van Soest, R. W. M., 1993a. Distribution of sponges on the Mauritanian continental shelf. Hydrobiologia 258: 95-106.

Van Soest, R. W. M., 1993b. Affinities of the marine demosponge fauna of the Cape Verde Islands and Tropical West Africa. Courier Forschungsinstitute Senckenberg 159: 205-219.

Van Soest, R. W. M., 1994. Demosponge distribution patterns. In Van Soest, R. W. M., Th. M. G. Van Kempen \& J. C. Braekman (eds), Sponges in Time and Space. Balkema, Rotterdam: 213-223.

Van Soest, R. W. M. \& S. Weinberg, 1980. A note on the sponges and octocorals from Sherkin Island and Lough Hyne, Co. Cork. Irish Naturalists Journal 20: 1-14.

Van Soest, R. W. M., J. D. Guiterman \& M. Sayer, 1983. Sponges from Roaringwater Bay and Lough Hyne. Journal of Sherkin Island 1: 35-49.

Van Soest, R. W. M., B. E. Picton \& C. Morrow, 2000. Sponges of the North East Atlantic. World Biodiversity Database CD-ROM Series, ETI. University of Amsterdam, The Netherlands.

Van Soest, R. W. M., D. F. R. Cleary, M. J. de Kluijver, M. S. S. Lavaleye, C. Maier \& F. C. van Duyl, 2007a. Sponge diversity and community composition in Irish bathyal coral reefs. Contributions to Zoology 76: 121-142.

Van Soest, R. W. M., M. J. Kluijver, P. H. Van Bragt, M. Faasse, R. Nijland, E. J. Beglinger, W. H. De Weerdt \& N. J. de Voogd, 2007b. Sponge invaders in Dutch coastal waters. Journal of the Marine Biological Association of the United Kingdom 87: 1733-1748.

Van Soest, R. W. M, N. Boury-Esnault, J. N. A. Hooper, K. Rützler, N. J. de Voogd, B. Alvarez, E. Hajdu, A. B. Pisera, J. Vacelet, R. Manconi, C. Schoenberg, D. Janussen, K. R. Tabachnick \& M. Klautau, 2009. World Porifera Database [available online at http://www.marinespecies. org/porifera]. Accessed 15 Jan 2009.

Voultsiadou, E., 2005. Demosponge distribution in the Eastern Mediterranean: a NW-SE gradient. Helgoland Marine Research 59: 237-251.

Voultsiadou, E., 2009. Reevaluating sponge diversity and distribution in the Mediterranean Sea. Hydrobiologia 629: $1-12$.

Warwick, R. M. \& K. R. Clarke, 1995. New biodiversity measures reveal a decrease in taxonomic distinctness with increasing stress. Marine Ecology Progress Series 129: 301-305.

Warwick, R. M. \& K. R. Clarke, 1998. Taxonomic distinctness and environmental assessment. Journal of Applied Ecology 35: 532-543.

Xavier, J. R., 2003. Esponjas marinhas (Porifera: Demospongiae e Calcarea) do litoral de São Miguel - Açores: abordagem taxonómica. Tese de licenciatura, Universidade dos Açores.

Xavier, J. R. \& R. W. M. Van Soest, 2007. Demosponge fauna of Ormonde and Gettysburg Seamounts (Gorringe Bank, Northeast Atlantic): diversity and zoogeographical 
affinities. Journal of the Marine Biological Association of the United Kingdom 87: 1643-1653.

Xavier, J. R., R. W. M. Van Soest, J. A. J. Breeuwer, A. M. F. Martins \& S. B. J. Menken, 2010a. Phylogeography of the poecilosclerid sponge Phorbas fictitius: genetic structure and refugia at oceanic islands. Contributions to Zoology 79: 119-129.

Xavier, J. R., P. G. Rachello-Dolmen, F. Parra-Velandia, C. H. L. Schönberg, J. A. J. Breeuwer \& R. W. M. Van Soest, 2010b. Molecular evidence of cryptic speciation in the "cosmopolitan" excavating sponge Cliona celata (Porifera, Clionaidae). Molecular Phylogenetics and Evolution 56: 13-20.

Yokoyama, Y., K. Lambeck, P. Deckker, P. Johnston \& L. K. Fifield, 2000. Timing of the Last Glacial Maximum from observed sea-level minima. Nature 406: 713-716. 